Article

\title{
Synthesis and Application of a Cationic Polyamine as Yankee Dryer Coating Agent for the Tissue Paper-Making Process
}

\author{
Cesar Valencia ${ }^{1}$ (), Yamid Valencia ${ }^{1}$ and Carlos David Grande Tovar ${ }^{2, *}(\mathbb{C}$ \\ 1 Área de Investigación, Desarrollo e Innovación, Disproquin S.A.S., Calle 93 Número 7u-2a, Vía \\ Cali-Juanchito 760021, Colombia; analista.id2@disproquin.com.co (C.V.); \\ analista.id@disproquin.com.co (Y.V.) \\ 2 Grupo de Investigación de Fotoquímica y Fotobiología, Universidad del Atlántico, Carrera 30 Número 8-49, \\ Puerto Colombia 081008, Colombia \\ * Correspondence: carlosgrande@mail.uniatlantico.edu.co
}

Received: 25 November 2019; Accepted: 6 January 2020; Published: 9 January 2020

check for updates

\begin{abstract}
Tissue paper is of high importance worldwide and, continuously, research is focused on improvements of the softening and durability properties of the paper which depend specifically on the production process. Polyamide-amine-epichlorohydrin (PAE) resins along with release agents are widely used to adhere the paper to the yankee dryer (creping cylinder) in paper manufacture. Nevertheless, these resins are highly cationic and they normally adhere in excess to the paper which negatively affects the creping process and the quality of the paper. For this reason, a low cationic polyamine-epichlorohydrin coating (Polycoat $38^{\circledR}$ ) was synthesized from a diamine supplied by Disproquin S.A.S. and epichlorohydrin. The analysis of the synthesized polymer was carried out by Fourier transform infrared spectroscopy (FTIR) and nuclear magnetic resonance ( $\left.{ }^{1} \mathrm{H}-\mathrm{NMR}\right)$. The molecular weight of the polymer was obtained by gel permeation chromatography (GPC), physical-chemical properties such as kinematic viscosity, percentage of solids, density, charge density were measured and compared with a commercial PAE resin (Dispro620 ${ }^{\circledR}$ ) Thermal stability of the Polycoat $38^{\circledR}$ and glass transition temperature in presence of a release agent (Disprosol $17^{\circledR}$ ) were also evaluated by thermogravimetric analysis (TGA) and differential scanning calorimetry (DSC), respectively. Finally, a peel adhesion test and an absorption durability assessment were carried out together with the evaluation of the creeping efficiency of the paper by caliber and tensile measurements in a tissue (towel paper) production plant, demonstrating a superior performance in the paper creping process as compared to some commercially available products.
\end{abstract}

Keywords: coating agent; paper creping; polyamine-epichlorohydrin resin; release agent; yankee dryer

\section{Introduction}

Coatings are adhesive compounds which facilitate the operation of the creping machines since they allow the paper to adhere to the yankee dryer's surface at the last step of the tissue paper conversion [1]. These are used in conjunction with a release agent that controls the hardness of the coating and its adhesion, allowing the demolding of the paper once in contact with the creping blade as shown in Figure 1 [1].

Coating agents commercially available, such as Discrepel $\mathrm{HRC} \mathrm{C}^{\circledR}, \mathrm{Kymene} 557 \mathrm{H}^{\circledR}$, Rezosol $8223^{\circledR}$, and others [2], are synthesized from various available additives, such as polyamine-amide resins mixed with polyvinyl alcohols and ethoxylated alcohols [2]. Unfortunately, they tend to develop less re-wettable hard coatings due to the high cationic charge of the polymer [3,4]. The described 
situation causes a strong adhesion and blade vibrations, which in turn generates non-uniform creping and profile of the paper, blade wear, and damage to the surface of the drying cylinder [5]. On the other hand, the most common release agents usually have the combination of fatty alcohols, glycerol, and non-ionic emulsifying agents such as lecithin $[6,7]$.

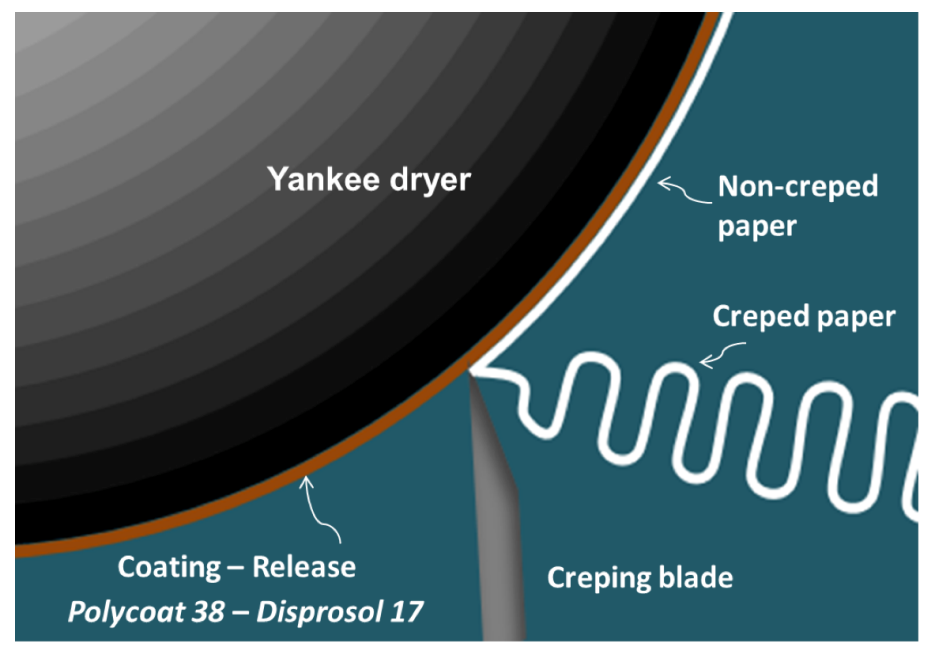

Figure 1. Scheme of the creping process using a coating-release agent in the yankee dryer.

The main limitation is that all the components must be completely emulsified along with the coating in the yankee's surface during application since the hardness and adhesiveness should be equilibrated depending on the needs $[7,8]$. The previous requirement implies that during the application the emulsions must be stable and homogeneous, which normally does not occur when the most common release agents are used [8]. In general, these types of emulsions are easily separated and their application in the yankee leads, for example, to non-homogeneous coating, which is traumatic for the drying process affecting the formation of the tissue paper rolls and also yankee's surface could be deteriorated $[5,7]$. The shelf-life of the doctor creping blade could be reduced and the different adherence intensity to the paper sheet deteriorates its creping process and the final quality of the paper $[5,7]$.

Therefore, there is a great demand for a crepe coating-release couple that remains soft and re-wettable under the drying conditions found in creping [1,7]. It is necessary that produces high creping efficiency while generating a high-quality paper [9], less creping blade wear, and greater protection for the yankee to generate a uniform release of the paper and that does not produce bursting problems on paper rolls [7].

Promising coatings that seems to accomplish these requirements are the polyamine-based resins. These resins show charge density and structures related to the fibers of the pulp which generates lower dry strength in the paper than the classical PAE $[10,11]$. In addition, they have less adhesion and hardness properties, controllable during the polymerization process [12] in order to have properties required by the yankee [5]. At the same time, release agents based on vegetal oil surfactants present stable emulsions that control this type of coatings once they are applied to the yankee $[13,14]$, which inspire us for the present development.

For this reason, a new coating (Polycoat $38^{\circledR}$ ) was designed based on a diamine and epichlorohydrin [15] to generate a cationic polyamine whose structure, viscosity, percentage of solids, charge density, and tensile measures indicates a greater adhesion-release balance. Therefore, greater rewetting properties together with the interaction of a mineral oil-based release agent (Disprosol $\left.17^{\circledR}\right)$, allows a more stable coating on the yankee [1], with high resistance, greater smoothness, and a better absorbency of the paper while the creping took place at a paper mill of a tissue production plant $[5,7,8]$. 


\section{Materials and Methods}

\subsection{Materials}

All the reagents used in this research (U.S.P grade) were obtained from Sigma-Aldrich (Palo Alto, CA, USA) and used without further purification unless otherwise stated.

\subsection{Synthesis of the Polyamine Resin Polycoat $38^{\circledR}$}

Polycoat $38^{\circledR}$, which is a polyamine obtained by the A. Allen modified method [15], uses a difunctional polyamine or diamine with epichlorohydrin for the polymer synthesis with the addition of polyvinyl alcohol between $25-60^{\circ} \mathrm{C}$, and it is advantageous providing strong adhesion of the cellulosic fiber web to the dryer surface during the creping process to attain a soft, bulky tissue paper web $[15,16]$.

The diamine was placed in a $100 \mathrm{~kg}$ industrial pilot reactor with double jacket coupled to a steam and a water recirculatory ice bank (Disproquin S.A.S., Candelaria, Colombia). Aqueduct water was added to the pilot in order to reach $38 \mathrm{wt} \%$ solids. It was then heated to $50{ }^{\circ} \mathrm{C}$ and stirred. A sample of $8.50 \mathrm{~kg}$ of epichlorohydrin were slowly added at room temperature with agitation. The exothermic reaction reached a temperature of $150^{\circ} \mathrm{C}$ and it was stirred for $4 \mathrm{~h}$. Finally, when a kinematic viscosity between 400 and $500 \mathrm{cP}$ was reached, a solution of $0.1 \%$ sulfuric acid was added to stop the reaction. The resultant polyamine cationic product was stored in plastic drums [4,15-18].

\subsection{Characterization}

\subsubsection{Characterization of the Polycoat $38^{\circledR}$}

FTIR measurements were performed on an infrared equipment, Thermo brand model NIcolet 6700 (ThermoFisher Scientific, Waltham, MA, USA), using KBr tablets. ${ }^{1} \mathrm{H}-\mathrm{NMR}$ measurements were performed on a $400 \mathrm{MHz}$ NMR Bruker Ultra Shield (Bruker Corporation, Billerica, MA, USA) using $\mathrm{D}_{2} \mathrm{O}$ as a solvent. GPC measurements for the molecular weight determination of the polymer were performed using a gel permeation chromatograph Agilent 1200 (Agilent Technologies, Santa Clara, CA, USA) with 2 intercrossed polymer columns Shodex ohpak (Showa Denko, Tokyo, Japan) as the stationary phase and $\mathrm{NaNO}_{3} 0.15 \mathrm{M} / \mathrm{HCOOH} 0.5 \mathrm{M}$ as the mobile phase, using pullulan standards for the calibration curve and a refractive index detector. Thermogravimetric analysis was performed on a TGA-2050 thermogravimetric analyzer (TA instrument, New Castle, DE, USA) adjusted in a working temperature range between $25-400^{\circ} \mathrm{C}$. DSC measurements were made in a DSCQ 100 (TA instrument, New Castle, DE, USA). The ion demand of the resin was measured with an automatic particle charge analyzer (AFG Analytic GMBH, Leipzig, Germany). The non-volatile percentage was calculated using Equation (1).

$$
\text { \%Solids }=W_{\mathrm{f}} / W_{\mathrm{i}}
$$

where $W_{\mathrm{i}}$ was the initial weight of the sample and $W_{\mathrm{f}}$ was the final weight after heating at $105^{\circ} \mathrm{C}$ during one hour in an oven (Memmert Gmbh + Co. KG, Buchenbach, Germany).

The kinematic viscosity was measured to $500 \mathrm{~g}$ of the sample, using the needle 1 at 50 RPM and the respective Brookfield RVT viscometer (Brookfield Engineering Laboratories Inc., Middleborough, MA, USA). The density was calculated by weighing $1.000 \mathrm{~mL}$ of the sample, added with a micropipette (Eppendorf, Hamburg, Germany). The $\mathrm{pH}$ was measured with a Hanna $\mathrm{pH}$ meter (Hanna Instruments Inc., Woonsocket, RI, USA). Peel adhesion test of the coating was carried out with a horizontal tensile tester ZB-WL30 (Hangzhou Zhibang Automation Technology Co., Ltd., Zhejiang, China) to tissue hand-sheets with $30 \mathrm{~g} / \mathrm{m}^{2}$ grammage, $5.5 \mathrm{~cm}$ long and $1.5 \mathrm{~cm}$ with, attached to a standardized aluminum panel $9.5 \mathrm{~cm}$ long and $1.5 \mathrm{~cm}$ width. In the procedure, $0.04 \mathrm{~mL}$ of the coating is added to the panel and spread with a bronze applicator. The paper is adhered to the panel at $105^{\circ} \mathrm{C}$ in an oven (Memmert Gmbh + Co. KG, Buchenbach, Germany) and its exposed edge is tightened with the tensile clamp, which removes the strip at a speed of $10 \mathrm{~mm} / \mathrm{min}$ and records the force required to detach it [2]. Finally, 
the coating durability was evaluated by the degree of swelling and erosion [5], where the coating was immersed in distilled water at room temperature. After $24 \mathrm{~h}$, the coating was filtered, the water residues were dried with filter paper and wet weighted, the sample was put in an oven (Memmert $\mathrm{Gmbh}+\mathrm{Co} . \mathrm{KG}$, Buchenbach, Germany) for $24 \mathrm{~h}$ at $37^{\circ} \mathrm{C}$. Its dry weight was recorded and the following Equation (2) was used for the calculation.

$$
\% \text { Erosion }=\left(\left(W_{\mathrm{i}}-W_{\mathrm{f}}\right) /\left(W_{\mathrm{i}}\right)\right) \times 100
$$

where $W_{\mathrm{i}}$ is the wet weight and $W_{\mathrm{f}}$ is the final dry weight.

\subsubsection{Characterization of the Tissue Creping Paper}

The hand sheets for the analysis of the paper were obtained folding 16 times a $2.65 \mathrm{~m}^{2}$ sheet of a paper roll which is then cut using an Alfa pneumatic precision cutter (Thwing-Albert Instruments Company, West Berlin, NJ, USA). As a result, 16 sheets whit $22.5 \mathrm{~cm}^{2}$ area and grammage between 14.5 and $15.5 \mathrm{~g} / \mathrm{m}^{2}$ were obtained. Caliber of the 16 sheets was measured with a digital micrometer (testing machines Inc., Las Vegas, NV, USA). Tensile strength and elongation of 8 sheets in machine direction (MD) and 8 in cross machine direction (CD) were measured using a QC-1000 Tensile Tester (Thwing-Albert Instruments Company, West Berlin, NJ, USA).

\subsection{Application of the Polycoat $38^{\circledR}$ and the Disprosol $17^{\circledR}$ in the Yankee Dryer}

Both products were added trough a shower at 35 psi using two dosing pumps, the Polycoat 38 and the Disprosol $17^{\circledR}$ where dosed with a $1.4: 2$ ratio to a $2.65 \mathrm{~m}$ wide and $5.2 \mathrm{~m}$ diameter yankee dryer working at a speed of $400 \mathrm{~m} / \mathrm{min}$, with internal steam pressure of $112 \mathrm{psi}$ and an external temperature of $105^{\circ} \mathrm{C}$, where the doctor creping blade exerts a pressure of $45 \mathrm{psi}$ on the product which allows $14.5-15.5 \mathrm{~g} / \mathrm{m}^{2}$ grammage paper rolls with weights between $950-1150 \mathrm{~kg}$ to be produced at a speed of $336 \mathrm{~m} / \mathrm{min}$, leading to the fabrication of triple sheet towels in a Colombian toilet paper manufacturing company. Creping and cleaning blades wear were measured using a digital microscope camera (Microview Science and Technology Co., Ltd., Beijing, China).

To complement the previous information, a graphical abstract of the methodology used from the coating synthesis to its application in the paper mill can be observed in the Figure 2.

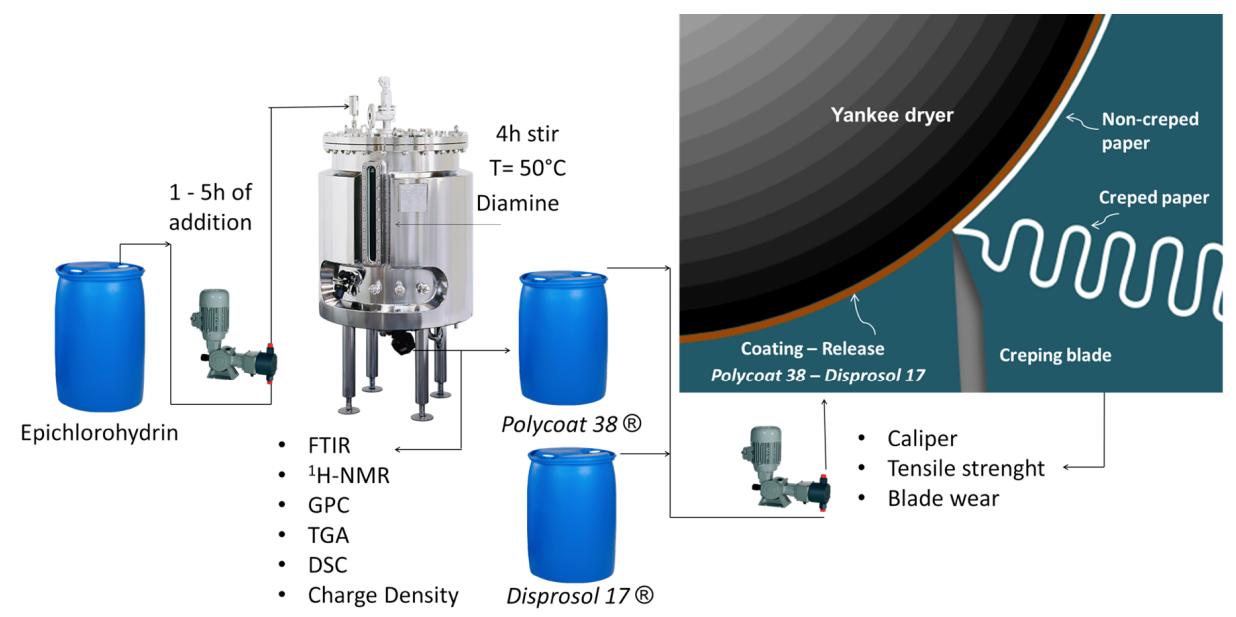

Figure 2. Graphical abstract of the synthesis and application of the Polycoat $38^{\circledR}$ coating in the yankee dryer. 


\section{Results and Discussion}

\subsection{FTIR Analysis of the Polycoat $38^{\circledR}$ Resin}

The FTIR spectrum of the polymer resin is presented in Figure 3. The characteristic bands of the cationic polyamine $[10,19,20]$ are observed. At $3311 \mathrm{~cm}^{-1}$ the broad tension vibration band of the O-H bond is observed. The band at $1070 \mathrm{~cm}^{-1}$ corresponds to the $\mathrm{C}-\mathrm{O}$ bond in the $\mathrm{C}-\mathrm{OH}$ group that allows the interaction with the fiber and that is part of the azetidine ring [21]. On the other hand, at $1218 \mathrm{~cm}^{-1}$ is the tension band of the $\mathrm{C}-\mathrm{N}$ bond presented in the quaternary nitrogen of the azetidine ring [10], also, the vibration band of the $\mathrm{N}-\mathrm{H}$ caused by the interaction between the added acid and the groups of free amines appears in $1623 \mathrm{~cm}^{-1}$ [15] Finally, at $2946 \mathrm{~cm}^{-1}$, the C-H tension vibration band of the methylene groups in the main chain of the polymer is observed [22].

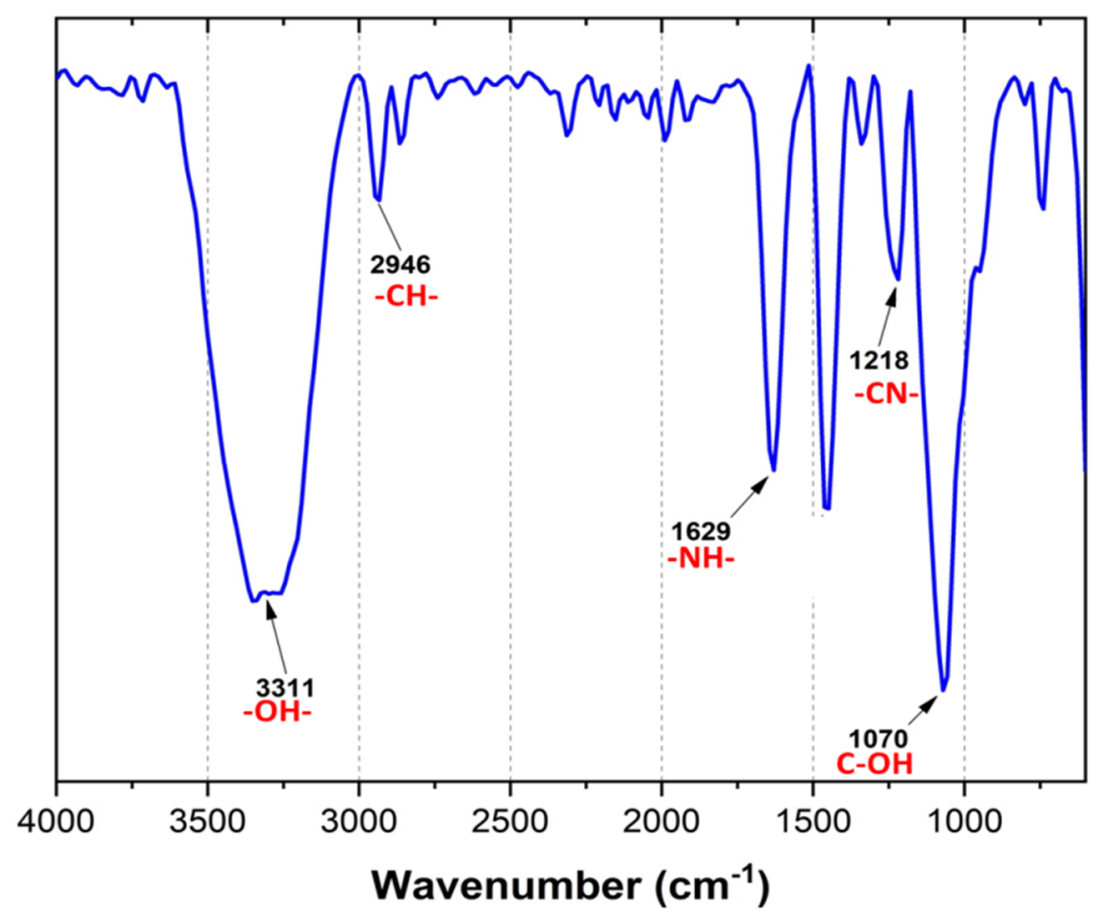

Figure 3. Fourier transform infrared spectroscopy (FTIR) spectrum of the polyamine (Polycoat $38^{\circledR}$ ) resin synthesized.

\section{2. ${ }^{1} H-N M R$ Analysis of the Polycoat $38^{\circledR}$ Resin}

In the ${ }^{1} \mathrm{H}-\mathrm{NMR}$ spectrum (Figure 4 ), the characteristic signals of the protons presented in the coating resin can be observed $[23,25]$. The signals at chemical shifts of 0.96 and 1.66 ppm correspond to the protons of the $\mathrm{CH}_{2}$ and $\mathrm{CH}$ groups of the azetidine ring, where quaternary nitrogen are generated and relate with $\mathrm{OH}$ groups at the end of the ring [25]. These $\mathrm{OH}$ groups tend to form hydrogen bonds with the cellulose and hemicellulose (polyoses) allowing the adhesion of the paper to the yankee and a posterior detachment once it comes into contact with the creping blade [24]. On the other hand, the multiplet presented between 2.89 and $3.04 \mathrm{ppm}$ are characteristic of the protons presented in the $\mathrm{CH}$ groups of the main polymer backbone [4,25]. 


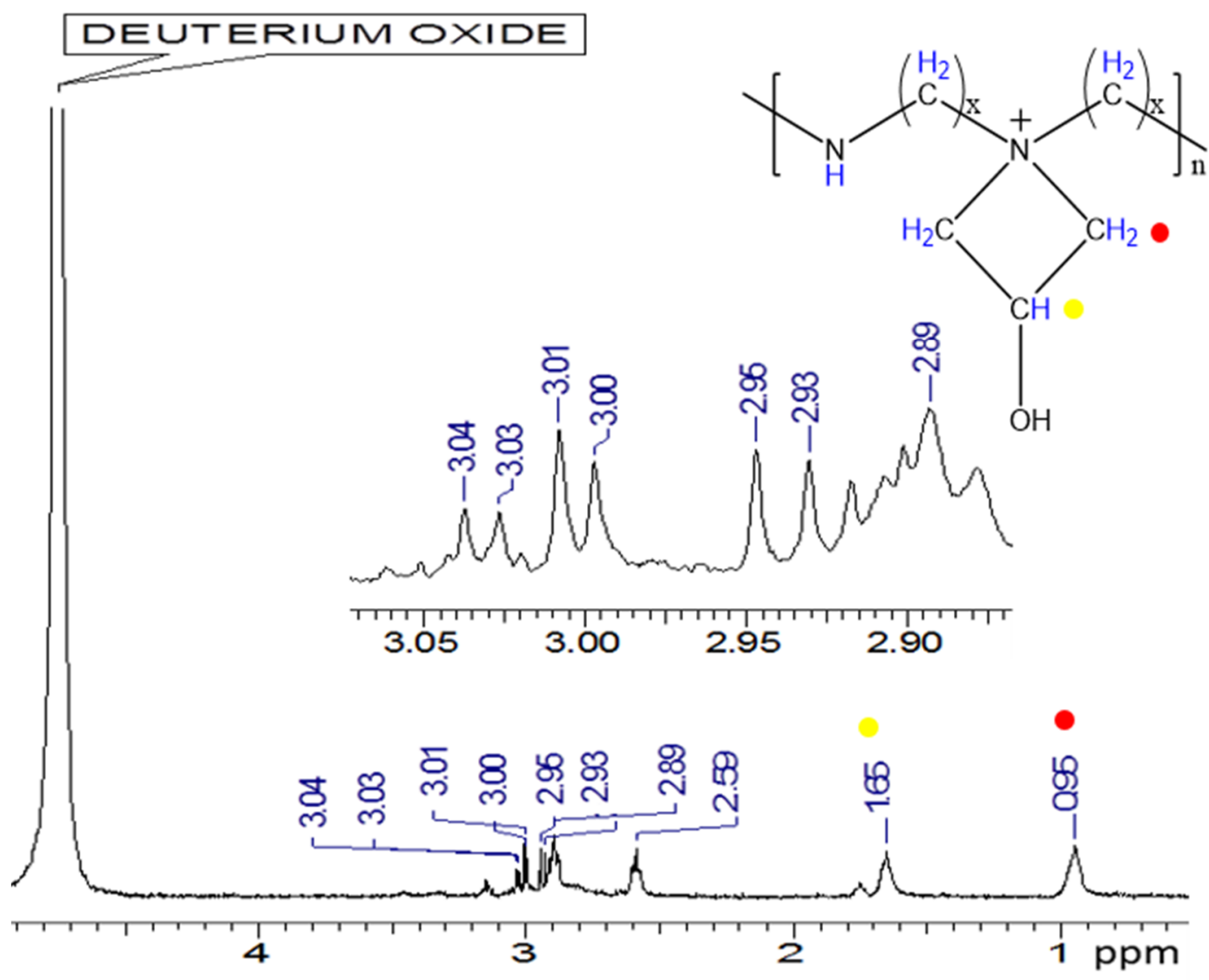

Figure 4. Nuclear magnetic resonance $\left({ }^{1} \mathrm{H}-\mathrm{NMR}\right)$ spectrum of the polyamine (Polycoat $38^{\circledR}$ ) resin synthesized.

Finally, a signal from the $\mathrm{NH}$ and the $\mathrm{OH}$ protons of the chain would be expected around $8 \mathrm{ppm}$. However, the signal is not observed due to the presence of the deuterated solvent that causes an exchange of protons with the hydrogens of this groups and decreases the intensity of the signals [25]. The figure also shows the possible structure of the cationic polymer and its corresponding azetidine ring [4].

\subsection{Molecular Weight Determination of the Polycoat $38^{\circledR}$ Resin}

The molecular weight of the resin was calculated using gel permeation chromatography technique. Retention time of the peak corresponding to the polyamine yield an average molecular weight $(\mathrm{Mw})$ of $3131 \mathrm{~g} / \mathrm{mol}$ and an average number molecular weight (Mn) of $2890 \mathrm{~g} / \mathrm{mol}$.

Mw was higher since it corresponds to higher molecular weight chains, while Mn is sensitive to low molecular weight chains [22]. On the other hand, these values allowed to elucidate the polydispersity index (PI), which in this case corresponded to 1.08. This value is close to the unit and indicates that the lengths of the chains are practically equal [26]. That will produce a homogeneous distribution on the surface of the yankee, which in turn will generate an optimal contact with the sheet of paper to crepe without the presence of holes caused by spaces between chains of high and low molecular weight [27]. Likewise, the distribution of the cations across the polymer are uniform decreasing the residual epichlorohydrin of the synthetized resin which is an environmental requirement for these processes [28]. 


\subsection{Thermogravimetric Analysis (TGA) of the Polycoat $38^{\circledR}$ Resin}

Figure 5 shows the weight loss of the polymer in function of the temperature. The first loss is due to the amount of water retained in the interstices of the polymer which tend to evaporate between 45 and $100{ }^{\circ} \mathrm{C}$ [29]. The second loss is observed between 351 and $378^{\circ} \mathrm{C}$, corresponding to the rupture of the main chains in the polymer, leading to its degradation [25]. The given temperature is higher than the working temperature of the surface of the yankee [5], which indicates that there will be no problems due to the deterioration and subsequent breakage of the main chains of the polymer and the opening of the azetidine rings [5], needed to adhere the paper through $\mathrm{OH}$ cellulose groups on the yankee's surface [30].This indicates that a loss of durability of the coating will not be present since the yankee surface temperature is lesser than the coating degradation temperature [5], meaning that the coating performance will not be affected, so loss of bulk in the finished paper rolls and cross machine direction profile issues of uniformity in the produced paper roll will not be observed [7].

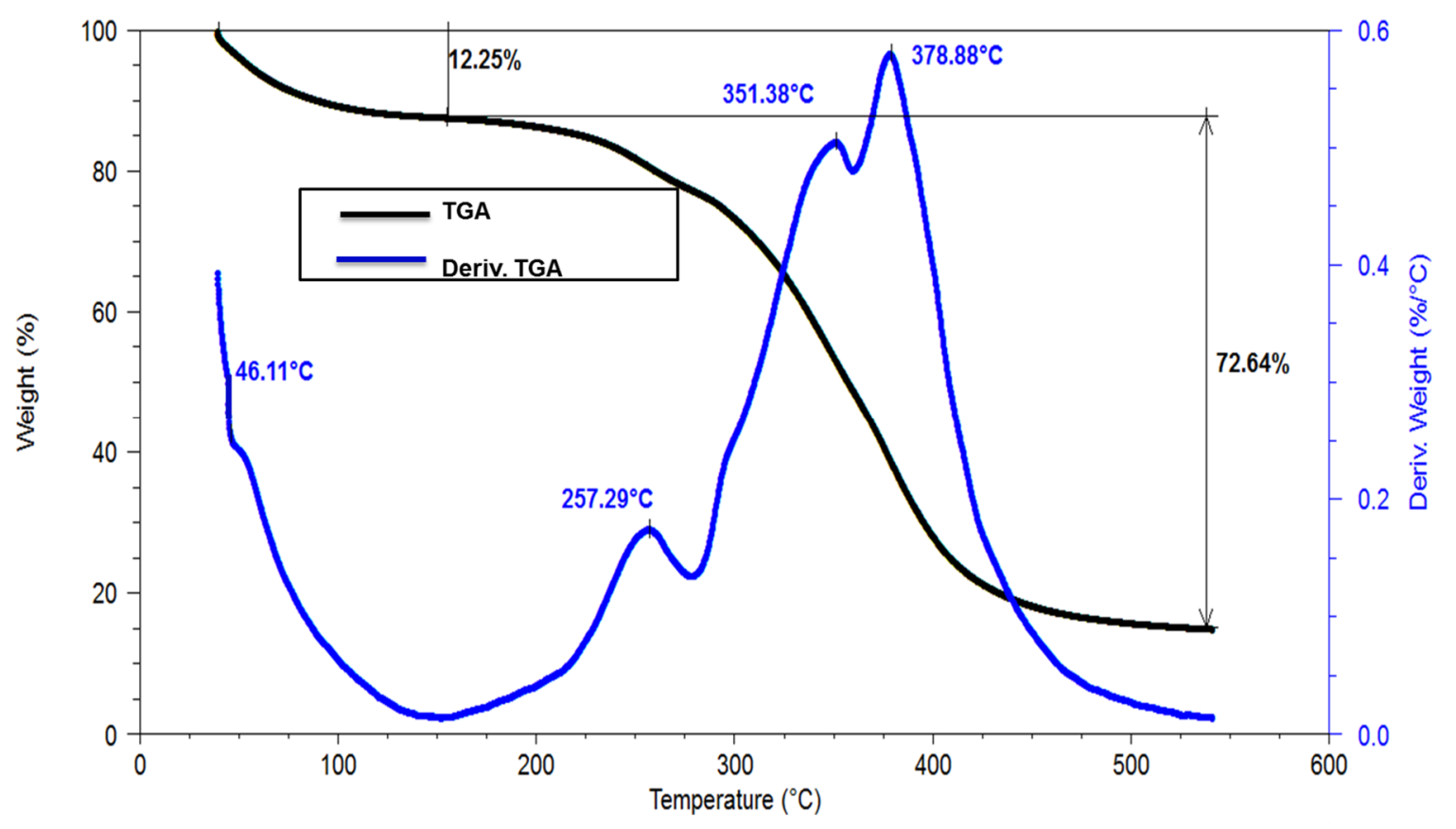

Figure 5. Thermogravimetric analysis of the polyamine (Polycoat $\left.38^{\circledR}\right)$ resin synthesized.

\subsection{Differential Scanning Calorimetry (DSC) of the PAE Resin}

The differential scanning calorimetry analysis is of utmost importance because it shows the vitreous transition temperatures $\left(T_{\mathrm{g}}\right)$ of the resin [31]. The value of $T_{\mathrm{g}}$ on the central axis is between the range in which the behavior of the polymer is between glassy and rubbery [31]. The $T_{\mathrm{g}}$ needs to be greater than the yankee working temperature, otherwise the coating will not be soft enough to prevent blade chattering [5,7], wearing it out and producing a direct contact with the yankee by loss of thickness of the coating layer and a "smooth" crepe with more space between the crepe pockets [5].

In this case, the temperature of the yankee where the product was proven exceeded $100{ }^{\circ} \mathrm{C}$ and it can be seen in Figure 6 that the $T_{\mathrm{g}}$ of the coating alone and emulsified with release in a proportion similar to that used in the yankee were 85.7 and $77.7^{\circ} \mathrm{C}$, in which the polymer behaves like a thermoplastic rubber and is soft enough to produce high quality paper [31]. This DSC behavior was similar to other polyamide-based resins as reported by Huang K. et al. [32]. 

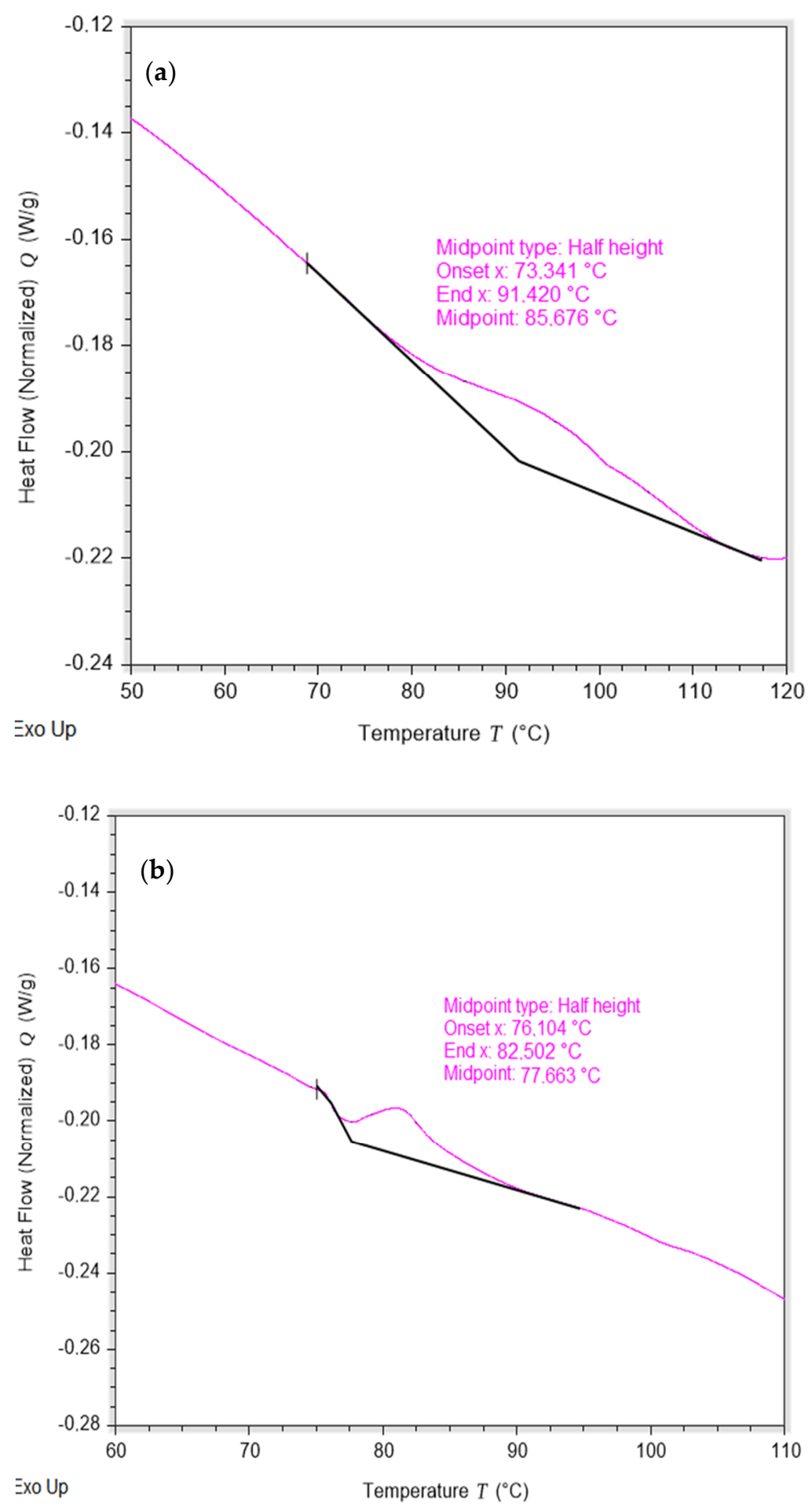

Figure 6. Differential scanning calorimetry (DSC) analysis of (a) the polycoat $38^{\circledR}$ resin synthetized and (b) emulsion of polycoat $38^{\circledR}$ and Disprosol $17^{\circledR}$.

It should be noted that each yankee operates at different temperatures depending on the requirements of the paper mill. If a slightly lower temperature is required, then the coating $T_{\mathrm{g}}$ should be slightly reduced by the addition of the release in a controlled way. For this reason, it is preferable that the temperature range of the product is not so wide in order to easily achieve subtle changes in the $T_{\mathrm{g}}$ of the polymer when it is required [31,33]. 
This behavior is observed in Figure 6 where the addition of Disprosol $17^{\circledR}$ to the coating decreases the $T_{\mathrm{g}}$ values slightly by increasing the softening of the chemical duple which was evidenced on the brittle property of the polymer under this temperature, generating a high adhesion coating that can be easily coupled to yankee dryers working at lower temperatures [33].

\subsection{Relative Adhesion of Polycoat $38^{\circledR}$}

The relative adhesion of the coating was measured by the peel adhesive method [2,5] and although the peel produced is not similar to that of a crepe blade, it is possible to measure the force required to release the paper without breaking it [2]. In the procedure, the metallic surface of the yankee is simulated at $105^{\circ} \mathrm{C}$ by a metal panel at the same temperature covered with coating and attached to a low grammage tissue paper in order to compare the Polycoat $38^{\circledR}$ with other commercial coatings $[2,5,15]$.

Table 1 shows the results of relative adhesion of different coatings together with Polycoat $38^{\circledR}$.

Table 1. Relative adhesion of different coatings commercially available.

\begin{tabular}{cc}
\hline Coating & Relative Adhesion (gF/3in) \\
\hline PAE Dispro620 $0^{\circledR}$ & 2823 \\
Discrepel HRC ${ }^{\circledR}$ & 1595 \\
Glyoxilated Polydadmac & 1179 \\
Polycoat 38 & 1078 \\
Polycoat 38:Disprosol 17 ${ }^{\circledR}(1: 1,4)$ & 966 \\
CR180 & N/A \\
\hline
\end{tabular}

N/A: No adhesion.

As observed in Table 1, the adhesion of the Polycoat $38^{\circledR}$ is lower than a PAE such as Dispro620 ${ }^{\circledR}$ [12], a high adhesion can lead to paper tearing during production because the tensile force required to tear paper of grammage $15 \mathrm{~g} / \mathrm{m}^{2}$ in general, is close to $600-1000 \mathrm{gF} / 3 \mathrm{in}$, which is a value far below than the given by the PAE. Likewise, other polymer-based coatings such ${ }^{\circledR}$ as Polydadmac or Discrepel HRC ${ }^{\circledR}$ can be highly cationic, which generate a strong adhesion of the paper to the yankee so that during their addition, a large amount of release would have to be added and thus decrease the adhesion but increase costs [10,11].

Adding for example, Disprosol $17^{\circledR}$ to the Polycoat $38^{\circledR}$, we observed a decrease of $10 \%$ in the adhesion of the coating, which apparently resembles more the dry strength of low grammage paper. Thus, it was possible to balance the adhesiveness of the coating on the yankee as reflected during the application and production of the paper $[7,8]$.

\subsection{Durability Test of the Polycoat $38^{\circledR}$}

The swelling erosion test of Polycoat $38^{\circledR}$ showed a polymer degradation of $95.9 \%$ after $24 \mathrm{~h}$ when comparing the initial swollen weight and the dry weight at $37^{\circ} \mathrm{C}$ using Equation (1) [5].

To evaluate the rewetting of the polymer, the time that takes for the yankee to rotate $360^{\circ}$ was used since it is the time in which another layer of coating is sprayed again [3]. This time value was equivalent to $0.26 \mathrm{~s}$ and was obtained from the data provided in Section 2.4. Using the result of the erosion of the polymer in $24 \mathrm{~h}$ and the yankee rotation time, a value of $0.0003 \%$ loss of durability during one yankee rotation was obtained. This result is practically negligible and means that there would not be degradation caused by humidity during the Polycoat $38^{\circledR}$ uses $[4,5]$.

\subsection{Quality Parameters of the Polycoat 38 Resin and Disprosol 17 Release Agent}

Physicochemical properties of the coating and the release agents were determined according to the quality requirements of both products and are presented in Table 2. 
Table 2. Quality parameters of the Coating (Polycoat 38) and the release agent (Disprosol 17).

\begin{tabular}{ccc}
\hline Parameter & ${\text { Polycoat } 38^{\circledR}}^{\circledR}$ & Disprosol 17 $^{\circledR}$ \\
\hline Appearance & Liquid & Liquid \\
Color & Ambar & Ambar \\
pH & $3.00-5.00$ & $6.00-8.00$ \\
Viscosity & $<600 \mathrm{cP}$ & $<400 \mathrm{cP}$ \\
Total solids & $38.00 \%$ & $100 \%$ \\
Density & $1.01-1.03 \mathrm{~g} / \mathrm{mL}$ & $0.80-0.90$ \\
Charge density & $1800 \mathrm{mEq} / \mathrm{L}$ & $\mathrm{N} / \mathrm{A}$ \\
Dispersion & $\mathrm{N} / \mathrm{A}$ & $100 \%$ in water \\
\hline
\end{tabular}

N/A: Not applied.

The parameters shown in Table 1 provide information for industrial purposes and certain parameters such as $\mathrm{pH}$ must be within a range that can affect the performance of the yankee.

For example, the water of the tissue paper mills has a relatively neutral $\mathrm{pH}$, so the mixture of both products must be maintained between 5-9 to avoid deterioration in the yankee [34].

On the other hand, other parameters such as the viscosity of the products provide information on the product itself. A high viscosity is related to a lower flexibility of the polymer which may decrease the adhesiveness of the coating [35]. The release agent may be necessary to decrease the viscosity of the final product and its smoothness to achieve a more uniform creping [5,33].

Another important property for this type of cationic polymer-based resin is the charge density. Charge density is related to the percentage of azetidine rings formed in the resin which are those that adhere to the fiber when the paper passes through the yankee [30]. A higher charge indicates greater adhesiveness and although it is a desirable property an excess may cause an excessive paper sticking causing deterioration of the coating when comes in contact with the creping blade [7]. This undesirable property is generally provided by top-charge resins such as PAEs, which have been presenting these problems despite their broad application [3].

When comparing the charge density of a PAE such as Dispro $620^{\circledR}$ manufactured at Disproquin S.A.S $(2700 \mathrm{mEq} / \mathrm{L})$ with Polycoat $38^{\circledR}(1800 \mathrm{mEq} / \mathrm{L})$, it was inferred that there is a bigger amount of azetidinium groups in the PAE compared to the Polycoat $38^{\circledR}$. These groups are the reason of the interaction with the fiber [24] and although a good adhesion to the fiber is necessary, an excessively high charge generates a very strong adhesion, which leads to difficulties in the demolding and reduces the creping efficiency [3-5]. For this reason, the use of a PAE was discarded and the application was done with the Polycoat $38^{\circledR}$, which generated paper with desirable properties, as explained previously at Section 3.8 [36].

\subsection{Application of the Polycoat 38 Along with Disprosol 17 as Yankee Dryer Coating-Release Agent}

The interaction of the coating-release agents with the paper and the yankee dryer leads to a complex chemistry that has not been fully developed. In addition, this interaction is affected by multiple process such as changing a felt, a blade, cleaning a mesh or modifying a pick-up pressure [13]. For this reason, measurements of the effectiveness of products at the laboratory level are only approximate and are not necessarily reflected in the application [37]. Therefore, the analysis that is performed during production goes hand in hand with the experience of the operator and the process quality analyst. Thus, the application of the product was done starting at a ratio of 1:1 until reaching a dose of $7 \mathrm{~mL} / \mathrm{min}$ of Polycoat $38^{\circledR}$ and $10 \mathrm{~mL} / \mathrm{min}$ of Disprosol $17^{\circledR}(1: 1.4)$, which allowed an optimal profile of the paper roll in obtaining at a speed of $352 \mathrm{~m} / \mathrm{min}$. A balanced profile indicates that there are no bulges in the forming-roll caused by a poor distribution of chemicals or an unstable emulsion or a swelling in the paper.

On the other hand, during the application there were no bursts of paper in formation which indicates that there is an optimal adhesiveness generated by the Polycoat $38^{\circledR}$ and a good relationship 
between this and the release capacity of Disprosol $17^{\circledR}$ once the paper is creped. In addition, there was little noticeable wear on the creping and cleaning blades as shown in Figure 7.

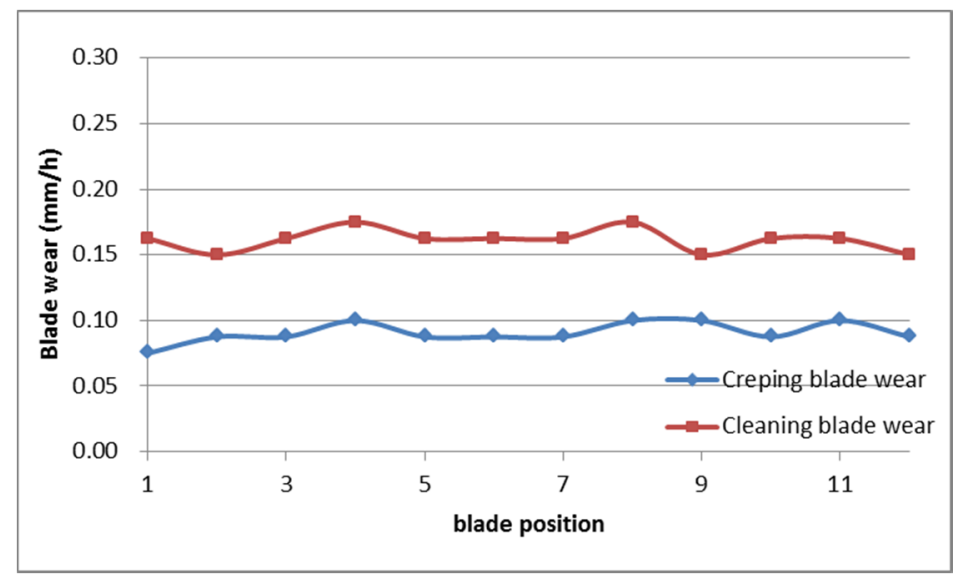

Figure 7. Creping and cleaning blade wear as a function of time.

As shown in Figure 7, the wear of both blades was minimal and even along their axes (position 1 to 11). In addition, when the creping blade was removed, did not present residue. This shows that the product covers uniformly the surface of the yankee and does not leave residue on the blade that could interfere with creping [5]. On the other hand, the cleaning blade tends to have a slightly higher damage compared to the creping blade since it removes the coating-release residue in the yankee and its pressure against the cylinder is higher.

\subsection{Quality Parameters of the Tissue Creping Paper Obtained}

\subsubsection{Caliber of the Tissue Creping Paper Obtained}

Caliber is one of the most important properties of tissue paper as it gives a ratio of the thickness of each sheet [38]. This parameter relates to the angle of the 'pockets' or 'crepes' per unit length [5]. Thus, the paper mill must maintain the caliber of the triple sheet tissue at a value lower than $12.0 \mathrm{~mm} / 100$ folds otherwise the creping would be irregular and the produced paper would be rough [38]. Caliber also allows to evaluate the quality of the coating. If caliber remains high throughout the application the adhesiveness of the coating would not be optimal [15], but if it remains low and rises in a short period of time, it would indicate that the hardness of the coating wears very quickly the blade [5].

The addition of the Polycoat-Disprosol agent generated paper with a caliber of $9.4 \mathrm{~mm} / 100$ folds. This indicates that the adhesiveness of the Polycoat $38^{\circledR}$ is of high quality and suggest that the wear of the blade was not representative and allowed to produce soft paper with optimal crepe [14].

\subsubsection{Tensile Strength and Stretch of the Creping Paper Obtained}

The measurement of the tensile strength of the paper does not allow to measure the efficiency of the coating-release directly, but it does allow to obtain the stretch force in the direction of the machine (MDS) [39]. With this value is possible to obtain the relative efficiency of a coating by using Equation (3) of stretch per creping unit [5], where $C E$ is the relative coating efficiency and $\% C$ is the creping percentage, which in turn is obtained using Equation (4) [5].

$$
\begin{gathered}
C E=M D S / \% C \\
\% C=(Y S-R S / Y S) \times 100 \%
\end{gathered}
$$

where $Y S$ is the speed of the yankee and $R S$ is the speed of the roll or winding cylinder of paper. When replacing these variables with the speed values given in Section 2.4 a result of $16 \% C$ is obtained. This 
$\% C$ was used in the Equation (3) along with the MDS which was $22 \%$ (calculated with the tensile tester), to obtain the coating efficiency of $1.4 \mathrm{MDS} / \% \mathrm{C}$.

Nevertheless, this efficiency value does not indicate much if it is not compared with the efficiency of other coatings agents found in the literature. In this case, the efficiency of the Polycoat $38^{\circledR}$ appears to be $45 \%$ higher than other coating systems such as the reported by Archer S. et al. [5] with a value of $0.94 \mathrm{MDS} / \% \mathrm{C}$, meaning that Polycoat $38^{\circledR}$ have the desired behavior of adhesiveness, softness, and durability for a high-quality creped tissue [9,39-41].

\section{Conclusions}

A polyamine-based resin (Polycoat $38^{\circledR}$ ) was synthetized by a modified A. Allen method, and was demonstrated to fulfill the requirements as a coating adhesive due to the presence of azetidine groups in its structure which allows interactions with polyoses of creped tissue paper. The presence of these groups was elucidated by FTIR, ${ }^{1} \mathrm{H}-\mathrm{RMN}$, and charge density analysis. These analyses, together with the GPC and thermogravimetric analysis permitted to know the polymer molecular weight, structure, its thermal stability, and its $T_{\mathrm{g}}$ along with Disprosol $17^{\circledR}$ (release agent) at the working temperature of a yankee dryer, were the coating-release agent was applied at a ratio of 1:1.4 respectively.

The addition of the chemical couple (coating-release) allowed a uniform profile along the paper roll of the tissue paper and minimal wear on the creping and cleaning blades evidenced in the low caliber of the paper and quality parameters. This also relates to the effectiveness of the coating which was $45 \%$ higher than others previously reported.

Author Contributions: Conceptualization, C.D.G.T.; Formal analysis, C.V.; Investigation, C.D.G.T., Y.V. and C.V.; Methodology, C.D.G.T., Y.V. and C.V.; Project administration, C.D.G.T.; Writing-original draft, C.D.G.T. and C.V.; Writing-review \& editing, C.D.G.T. and C.V. All authors have read and agreed to the published version of the manuscript.

Funding: This research was founded by DISPROQUIN S.A.S and COLCIENCIAS (Proyecto 64853 convocatoria 786 de beneficio tributario).

Acknowledgments: The authors acknowledge the company Colombiana Tissue for allowing the evaluation of the products in their paper mill.

Conflicts of Interest: The authors declare no conflict of interest.

\section{References}

1. The Basics of Creping in the Tissuemaking Process. Available online: https:/www.tissuestory.com/2018/09/ 26/the-basics-of-creping/ (accessed on 25 September 2019).

2. Michl PE, R.; Robert, A. Polyvinyl Alcohols in Combination With Glyoxlated-Vinyl Amide Polymers as Yankee Dryer Adhesive Compositions. U.S. Patent 5179150, 12 January 1993.

3. Simpson, J.T.; Us, T.N. Thermosetting Adhesives Comprising a Resin Having Azetidinium Functional Groups. U.S. Patent 7781501B2, 24 August 2019.

4. Gui, C.; Wang, G.; Wu, D.; Zhu, J.; Liu, X. Synthesis of a Bio-Based Polyamidoamine-Epichlorohydrin Resin and Its Application for Soy-Based Adhesives. Int. J. Adhes. Adhes. 2013, 44, 237-242. [CrossRef]

5. Archer, B.S.; Furman, G. Coating Space ${ }^{\mathrm{TM}}$ A 3-D View of Creping Cylinder Coatings. In Associação Brasileira Técnica de Celulose E Papel Conference; Nalco Company: Sao Paulo, Brazil, 2005; pp. 1-8.

6. Wang, S.; Zhang, F.; Chen, F.; Pang, Z. Preparation of a Crosslinking Cassava Starch Adhesive and Its Application in Coating Paper. Bioresour 2013, 8, 3574-3589. [CrossRef]

7. Furman, G.; Archer, S. Yankee Coating Systems-The Functional Interface. In Tissue World Americas Conference 2014; UBM Asia Trade Fairs Pte. Ltd.: Barcelona, Spain, 2014; pp. 34-53.

8. Furman, G.S.; Harry, X.; Su, W.; Griegoriev, V.A. Modifying Agent for Yankee Coatings. U.S. Patent 8101045B2, 24 January 2012.

9. van Beek, T.A.; Kuster, B.; Claassen, F.W.; Tienvieri, T.; Bertaud, F.; Lenon, G.; Petit-Conil, M.; Sierra-Alvarez, R. Fungal Bio-Treatment of Spruce Wood with Trametes Versicolor for Pitch Control: Influence on Extractive Contents, Pulping Process Parameters, Paper Quality and Effluent Toxicity. Bioresour. Technol. 2007, 98, 302-311. [CrossRef] 
10. Obokata, T.; Isogai, A. The Mechanism of Wet-Strength Development of Cellulose Sheets Prepared with Polyamideamine-Epichlorohydrin (PAE) Resin. Colloids Surf. A Physicochem. Eng. Asp. 2007, 302, 525-531. [CrossRef]

11. Wågberg, L.; Mirjam, B. On the Mechanism behind Wet Strength Development in Papers Containing Wet Strength Resins. Nord. Pulp Pap. Res. J. 2018, 8, 53-58. [CrossRef]

12. Kang, M.; Myung, S.J.; Jin, H.-J. Nylon 610 and Carbon Nanotube Composite by in Situ Interfacial Polymerization. Polymer 2006, 47, 3961-3966. [CrossRef]

13. Hagiopol, C.; Johnston, J. Chemistry of Modern Papermaking, 1st ed.; B/W Illustrations: Boca Raton, FL, USA, 2011.

14. Sharoyan, D.E.; Tunell, J.A. Method of Producing a Creping Paper and the Creping Paper Thereof. U.S. Patent 20160168798A1, 16 June 2016.

15. Allen, A. Methods of Making and Using Creping Adhesives Comprised of Polyamine-Epihalohydrin Resin/Poly (Vinylalcohol) Mixtures. U.S. Patent 2002/0173580A1, 21 November 2002.

16. Brady, R.L.; Us, D.E.; Allen, A.J.; Mary, J.; Rossi, F. Adhesive Composition of Low Molecular Weight Polyaminopolyamide-Epichlorohydrin (Pae) Resin and Protein. U.S. Patent 2008/0050602A1, 28 February 2008.

17. Häger, M.; Ese, M.; Sjöblom, J. Emulsion Inversion in an Oil-Surfactant-Water System Based on Model Naphthenic Acids under Alkaline Conditions. J. Dispers. Sci. Technol. 2005, 26, 673-682. [CrossRef]

18. Ese, M.; Kilpatrick, P.K. Stabilization of Water-in-Oil Emulsions by Naphthenic Acids and Their Salts: Model Compounds, Role of PH, and Soap:Acid Ratio. J. Dispers. Sci. Technol. 2004, 25, 253-261. [CrossRef]

19. Gao, D.; Fan, B.; Zhang, B.; Mi, Y.; Zhang, Y.; Gao, Z. Storage Stability of Polyamidoamine-Epichlorohydrin Resin and Its Effect on the Properties of Defatted Soybean Flour-Based Adhesives. Int. J. Adhes. Adhes. 2019, 91, 92-101. [CrossRef]

20. Kowalczyk, I. Synthesis, Molecular Structure and Spectral Properties of Quaternary Ammonium Derivatives of 1,1-Dimethyl-1,3-Propylenediamine. Molecules 2008, 13, 379-390. [CrossRef]

21. Huang, Z.; Gengenbach, T.; Tian, J.; Shen, W.; Garnier, G. The Role of Polyaminoamide-Epichlorohydrin (PAE) on Antibody Longevity in Bioactive Paper. Colloids Surf. B Biointerfaces 2017, 158, 197-202. [CrossRef] [PubMed]

22. Valencia, C.; Valencia, C.H.; Zuluaga, F.; Valencia, M.E.; Mina, J.H.; Grande-Tovar, C.D. Synthesis and Application of Scaffolds of Chitosan-Graphene Oxide by the Freeze-Drying Method for Tissue Regeneration. Molecules 2018, 23, 2651. [CrossRef] [PubMed]

23. Obokata, T.; Isogai, A. ${ }^{1} \mathrm{H}$ - and ${ }^{13} \mathrm{C}-\mathrm{NMR}$ Analyses of Aqueous Polyamideamine-Epichlorohydrin Resin Solutions. J. Aplp. Polym. Sci. 2004, 92, 1847-1854. [CrossRef]

24. Carr, M.E.; Doane, W.M.; Hamerstrand, G.E.; Hofreiter, B.T. Interpolymer from Starch Xanthate and Polyamide-Polyamine-Epichlorohydrin Resin: Structure and Papermaking Application. J. Appl. Polym. Sci. 1973, 17, 721-735. [CrossRef]

25. Devi, G.N.; Saranya, J.; Manjubaashini, N.; Thangadurai, T.D.; Roopan, S.M.; Chitra, S. Polyamidoaminoepichlorohydrin Resin a Novel Synthetic Anti-Corrosive Water Soluble Polymer for Mild Steel. Prog. Org. Coat. 2017, 109, 117-125. [CrossRef]

26. Zuluaga, F.; Gómez, F. Introducción a La Química de Polímeros, 3rd ed.; Programa Editorial Universidad del Valle: Cali, Colombia, 2015.

27. Schmied, F.J.; Teichert, C.; Kappel, L.; Hirn, U.; Bauer, W.; Schennach, R. What Holds Paper Together: Nanometre Scale Exploration of Bonding between Paper Fibres. Sci. Rep. 2013, 3, 2432-2437. [CrossRef]

28. Pei, L.; Lucy, C.A. Insight into the Stability of Poly(Diallydimethylammoniumchloride) and Polybrene Poly Cationic Coatings in Capillary Electrophoresis. J. Chromatogr. A 2014, 1365, 226-233. [CrossRef]

29. Valencia Junca, M.A.; Valencia, C.; Flórez López, E.; Delgado-Ospina, J.; Zapata, P.A.; Solano, M.; Grande Tovar, C.D. Chitosan Beads Incorporated with Essential Oil of Thymus Capitatus: Stability Studies on Red Tilapia Fillets. Biomolecules 2019, 9, 458. [CrossRef]

30. Obokata, T.; Yanagisawa, M.; Isogai, A. Characterization of Polyamideamine-Epichlorohydrin (PAE) Resin: Roles of Azetidinium Groups and Molecular Mass of PAE in Wet Strength Development of Paper Prepared with PAE. J. Appl. Polym. Sci. 2005, 97, 2249-2255. [CrossRef]

31. Rieger, E.; Manhart, A.; Wurm, F.R. Multihydroxy Polyamines by Living Anionic Polymerization of Aziridines. ACS Macro Lett. 2016, 5, 195-198. [CrossRef] 
32. Huang, K.; Xia, J.; Yang, X.; Li, M.; Ding, H. Properties and curing kinetics of C21-based reactive polyamides as epoxy-curing agents derived frpm tung oil. Polym. J. 2010, 42, 51-57. [CrossRef]

33. Thirtha, V.; Lehman, R.; Nosker, T. Effect of Additives on the Composition Dependent Glass Transition Variation in PS/PP Blends. J. Appl. Polym. Sci. 2008, 107, 3987-3992. [CrossRef]

34. McLeay, D.J.; Walden, C.C.; Munro, J.R. Effect of PH on Toxicity of Kraft Pulp and Paper Mill Effluent to Salmonid Fish in Fresh and Seawater. Water Res. 1979, 13, 249-254. [CrossRef]

35. Shah, N.; Mewada, R.K.; Mehta, T. Crosslinking of Starch and Its Effect on Viscosity Behaviour. Rev. Chem. Eng. 2016, 32, 265-270. [CrossRef]

36. Neal, C.W.; Forde-Kohler, L.J. Method for Creping Paper. U.S. Patent 6187138B1, 13 February 2019.

37. Scott, W. Principles of Wet End Chemistry, 1st ed.; Tappi Press: Atlanta, GA, USA, 1996.

38. Carson, C.G.; Popil, R.E. Examining Interrelationships between Caliper, Bending, and Tensile Stiffness of Paper in Testing Validation. TAPPI J. 2008, 7, 17-24.

39. Tissue Sheet Softness-Theory, Measurement, and Chemical Applications Which Can Improve It. Available online: https://www.tissuestory.com/2017/08/31/tissue-sheet-softness-theory-measurement-and-chemicalapplications-which-can-improve-it/ (accessed on 18 October 2019).

40. TAPPI. Tensile Properties Of Paper And Paperboard (Using Constant Rate Of Elongation Apparatus); Technical Association of the Pulp and Paper Industry: Peachtree Corners, GA, USA, 2006; pp. 1-28.

41. Kneller, J.F.; Park, L.G. Cross-Linked Poly(Aminoamides) as Yankee Dryer Adhesiver. U.S. Patent 5382323A, 17 January 1995.

(C) 2020 by the authors. Licensee MDPI, Basel, Switzerland. This article is an open access article distributed under the terms and conditions of the Creative Commons Attribution (CC BY) license (http://creativecommons.org/licenses/by/4.0/). 